\title{
FORUM SHOPPING EVIDENCE IN THE WORLD TRADE ORGANIZATION: A SOCIAL NETWORK ANALYSIS OF DISPUTES BETWEEN MEMBER STATES
}

\author{
EVIDÊNCIAS DE FORUM SHOPPING NA ORGANIZAÇÃO \\ MUNDIAL DO COMÉRCIO: UMA ANÁLISE DA REDE SOCIAL \\ DE DISPUTAS ENTRE ESTADOS-MEMBROS
}

\section{EVIDENCIAS DE FORUM SHOPPING EN LA ORGANIZACIÓN MUNDIAL DEL COMERCIO: UN ANÁLISIS DE LA RED SOCIAL DE DISPUTAS ENTRE ESTADOS MIEMBROS}

Kenyth Alves de Freitas

Doutorando em Administração - Escola de

Administração de Empresas de São Paulo

(EAESP), Fundação Getúlio Vargas (FGV), São

Paulo, Brasil

kenyth.freitas@gmail.com

\section{Bruno de Almeida Vilela}

Doutorando em Administração - Centro de Pósgraduação e Pesquisas em Administração (CEPEAD), Universidade Federal de Minas Gerais (UFMG), Belo Horizonte, Brasil

brunoavilela@gmail.com

\section{Rui Fernando Correia Ferreira}

Doutor em Administração - Centro de Pósgraduação e Pesquisas em Administração (CEPEAD), Universidade Federal de Minas Gerais (UFMG), Belo Horizonte, Brasil

Professor - FACEMG, Belo Horizonte - MG,

Brasil.

ruifernandof@gmail.com

André Edson Ribeiro de Souza Aprigio

Mestre em Relações Internacionais - Universidade

do Minho (UMINHO), Braga, Portugal

Doutorando em Ciência Política e Relações

Internacionais - Universidade do Minho

(UMINHO), Braga, Portugal
Contextus

ISSNe 2178-9258

Organização: Comitê Científico Interinstitucional Editor-Chefe: Diego de Queiroz Machado Avaliação: double blind review pelo SEER/OJS

Recebido em 17/10/2018

Aceito em 01/12/2018

$2^{a}$ versão aceita em $12 / 12 / 2018$

http://dx.doi.org/10.19094/contextus.v17i1.33949

\begin{abstract}
The intensification of trade between countries has led to the need to regulate the conduct of trading partners. The World Trade Organization (WTO) forum emerged with the mission of arbitrating these disputes and making trade fairer. However, many countries choose not to participate in this forum because of the financial and legal resources required to conduct the proceedings. The purpose of this research was to verify how the relations within the WTO were configurated in 2014. We identified the dichotomy between central and emerging countries through the concept of forum shopping. The most important actors in the network were shown to be the United States and the European Union, whereas small economies had low participation, especially African and Central American countries. Thus, this study shows that many WTO's members do not use its forum, which allows inferring they choose regional forums due to the restriction of resources.
\end{abstract}


Keywords: disputes; World Trade Organization (WTO); forum shopping; network analysis; globalization.

\section{RESUMO}

A intensificação do comércio entre os países levou à necessidade de regular a conduta dos parceiros comerciais. O fórum da Organização Mundial do Comércio surgiu com a missão de arbitrar essas disputas e tornar o comércio mais justo. No entanto, muitos países optam por não participar daquele fórum por causa dos recursos financeiros e legais necessários para conduzir o processo. O objetivo desta pesquisa foi verificar como as relações dentro da OMC se configuraram em 2014. Identificamos a dicotomia entre países centrais e emergentes através do conceito de forum shopping. Os Estados Unidos e a União Europeia se revelaram como os atores mais importantes da rede, enquanto as economias pequenas tiveram baixa participação, especialmente países da África e da América Central. Assim, este estudo mostra que muitos membros da $\mathrm{OMC}$ não utilizam seu fórum, o que permite inferir sua escolha de fóruns regionais devido à restrição de recursos.

Palavras-chave: disputas; Organização Mundial do Comércio (OMC); forum shopping; análise de redes; globalização

\section{RESUMEN}

La intensificación del comercio entre los países ha llevado a la necesidad de regular la conducta de los socios comerciales. El foro de la Organización Mundial del Comercio surgió con la misión de arbitrar esas disputas y hacer el comercio más justo. Sin embargo, muchos países optan por no participar en ese foro a causa de los recursos financieros y legales necesarios para conducir el proceso. El objetivo de esta investigación fue verificar cómo las relaciones dentro de la OMC se configuraron en 2014. Identificamos la dicotomía entre países centrales y emergentes a través del concepto de forum shopping. Los Estados Unidos y la Unión Europea se revelaron como los actores más importantes de la red, mientras que las economías pequeñas tuvieron baja participación, especialmente países de África y Centroamérica. Así, este estudio muestra que muchos miembros de la OMC no utilizan su foro, lo que permite inferir su elección de foros regionales debido a la restricción de recursos.

Palabras clave: disputas; Organización Mundial del Comercio (OMC); forum shopping; análisis de redes; globalización.

\section{INTRODUCTION}

International trade has undergone profound changes in the latest decades, such as intensified trade flows and expanded connection among countries. The value of international trade grew from USD\$ 11.7 trillion in 2006 to USD\$ 15.4 trillion in 2016, representing a growth of $31.6 \%$ in that period. The growth of agricultural products was even higher, advancing $70 \%$ over the same period (WORLD TRADE ORGANIZATION - WTO, 2018).

This trade growth was based on several economic trends, among which the creation of trade blocs and the dispersion of companies towards emerging countries. The former trend integrated the economies of regional countries through increased trade flows (FATTORE, 2018). The latter was directly supported by fiscal incentives offered by some nations, which allowed the globalization of several productive chains (ELMS; LOW, 2013; BALDWIN, 2012). The trade with other partners in their respective blocs represents $63 \%$ of exports in the European Union, 50\% in North American Free Trade Agreement (NAFTA), and 14\% in the Southern Common Market (MERCOSUR) (WTO, 2018).

Simultaneously, the increase of trade resulted in an increase of disputes between countries. With the aim of reducing these conflicts and encouraging trade growth, the WTO 
was officially established in 1995 as a forum to encompass the General Agreement on Tariffs and Trade (GATT) of 1947 and all agreements negotiated in the Uruguay Round in 1994. Approximately $98 \%$ of the value of world trade was realized by members of this organization in 2016 (WTO, 2018).

The WTO's Dispute Settlement Body is responsible for judging trade disputes between members. In a legal sense, the WTO examines the denunciation of one or more countries against other members of this organization for breach of the rules established in trade agreements. At the end of the process, it is defined if the country should be penalized and what should be the penalty (JACKSON, 2006; WTO, 2018; ROSENDORFF; SMITH, 2018).

However, Davis (2009) argues that developing countries tend not to seek the WTO's forum. One reason is that the process of spending is too high for their trade volume. In addition, there is a risk that developed countries, whose teams are better-prepared to work in the forum, impose their technical influence (FATTORE, 2012). The launch of the Doha Round in 2001 could be seen as a signal of a pursuit of other means of trade liberalization by emerging markets (HOPEWELL, 2017).

According to Fattore (2018), choosing different forums to arbitrate disputes is a common practice, which was aggravated by the growth of the number of regional blocs. As each bloc has its own rules, there are inner mechanisms to monitor partner compliance. However, the author reported that costs and technical difficulties affect the choice between forums, a phenomenon known as forum shopping.

Therefore, this study was guided by the following research question: How do the central and emerging countries act in the WTO's Dispute Settlement Body? The purpose of this research was to verify from social network analysis how the relations between the members of the WTO are configured and to identify the dichotomy between central and emerging countries while using the concept of forum shopping. The network-analyzed data were collected from active disputes from the WTO's Dispute Settlement Body forum in 2014.

The remainder of this article follows the subsequent order: section 2 presents a literature review of interdependence in international trade, provides an overview of WTO disputes, and raises the forum shopping concept. Section 3 describes the methodological steps used based on the social network method. Section 4 presents the results of the analysis and discussions on the configuration of the international trade scenario in the year studied. Finally, the main conclusions and orientations for future studies are presented in the last section. 


\section{THEORETICAL FRAMEWORK}

\subsection{Interdependence on international trade}

Global production chains are no longer focused only on their home-country but have to be present in countries that offer economic advantages, which resulted in their operational activities being spread throughout several countries (ZINN, 2012). However, international trade is not responsible only for the final product exchange, but also for the entire production process (ELMS; LOW, 2013; OECD, 2007; WTO, 2018).

International trade has grown significantly in recent decades (WTO, 2018). In addition to the expansion of multinational corporations, that growth can also be explained by trade barrier reduction, economic bloc expansion and free trade agreement proliferation (FATTORE, 2018). That new configuration of international trade facilitated the access of small and mediumsized companies to large markets and, simultaneously, a large proportion of consumers had access to imported products (BALDONE; SDOGATI; TAJOLI, 2007; ESTRIN; MEYER; PELLETIER, 2018).

According to the theory proposed by the Uppsala School, internationalization occurs after national market saturation. On a continuous and gradual path, companies seek lucrative opportunities in other countries through exportation or direct investments. In that sense, internationalization could be understood as a process in which companies gradually increase their presence abroad (JOHANSON; VAHLNE, 1977). These authors state that there is a sequential path to internationalization.

In general, it begins with light interaction through direct exportation. This interaction is strengthened as the company increases its knowledge of the local market and may eventually open a branch in the partner country. The input process generates market knowledge, allowing the company to select similar markets in other countries. According to Johanson and Vahlne (1977), the success of the internationalization model depends heavily on risks and uncertainties about the new market. The distance, be it physical or cultural, is regarded by this theory as an internationalization restriction in this initial phase.

The Uppsala model was revisited to include insights identified in the recent internationalization of companies. Johanson and Vahlne (2009) have now identified that internationalization is not carried out by isolated companies, but by networks of companies 
composed of suppliers and customers. Hence, companies insert themselves internationally only if their partners join them (JOHANSON; VAHLNE, 2009). Therefore, the increase in trade flow could result in a more elaborate and complex international trade (BANACLOCHE, 2017),

The fragmentation of production chains has led to a strong growth in international trade, which has become essential for the production of goods and services (ELMS; LOW, 2013). According to OECD (2007) estimations, $80 \%$ of global trade is carried out through global value chains, coordinated by multinational corporations with the aim of reducing production costs.

Bonaglia, Goldstein, and Mathews (2007) refer to the constitution of "a new geography of international trade." For the authors, this new reality is based on the reduction of trade barriers that allowed the globalization of production processes to advance rapidly. Sassen (1999, p. 6) argues that this is the "new geography of power," which means "a more transformative process of the state than the notion of a simple loss of power suggests. We are seeing a repositioning of the state in a broader field of power and a reconfiguring of the work of states."

The reorientation of global value chains' productive activities is based on the benefits obtained by concentrating them on firms that have specific advantages. This is related to their unique attributes or the intangible capacities that differentiate one firm from another. Firms seek competitive advantages by prioritizing the outsourcing of their activities to companies in countries which offer advantages, as an alternative to vertical integration (KAPLINSKY; READMAN, 2005; GIBBON; PONTE, 2005; ELMS; LOW, 2013).

Today, trade barriers must be understood in a broader sense. The old political barriers, based on tariffs or not, are no longer able to represent restrictions on trade growth. In order to better represent this concept, it is necessary to include all the costs involved to deliver the product to final consumers, excluding those directly related to production (BALDWIN, 2012; WTO, 2018).

Therefore, transportation costs, internal transactional and commercial costs define part of trade constraints. In these costs are included: freight, time costs, domestic costs of information, costs related to compliance, legal and regulatory costs, local distribution, customs clearance procedures, administrative bureaucracy, among others (BALDWIN, 2012; WTO, 2018).

Trade growth opportunities also pose challenges for companies and countries, because many agents argue that liberalization leads to the extreme specialization of nations. That is a 
serious problem for countries with low-level technology. Even in the developed countries, there are voices against free trade, especially concerned with the drain of jobs for emerging countries (BALDONE; SDOGATI; TAJOLI, 2007; CLING, 2014).

In contrast, despite the creation of the WTO, multilateral liberalization processes have not progressed since. The Doha Round, launched in 2001, has so far not reached its conclusion and frustrated particularly nations seeking greater liberalization for agricultural trade (CLING, 2014; WTO, 2018).

\subsection{Trade Disputes at the WTO}

The World Trade Organization was founded as a multilateral trade organization in 1995. A strong legal and institutional basis was inherited from the agreements established in the Uruguay Round and the GATT. Therefore, WTO was built as an important pillar of the current international trade, which established greater rights and duties for most of the countries (WTO, 2018).

At the end of World War II, the United States presented a document proposing multilateral rules for international trade, the so-called General Agreement on Tariffs and Trade (GATT). Fearful for the reoccurrence of protectionist policies as in the 1930s, the US government believed that trade cooperation would result in economic interdependence between countries, reducing the risks of a new world war (HOEKMAN; KOSTECKI, 1995, WTO, 2018).

The agreement was signed by 23 nations during the Geneva Round of 1947. It was considered a breakthrough at the time, due to the proposal to reduce barriers and guarantee market access by its signatories. However, the agreement did not provide the promotion of free trade, or at least the creation of guide conduct code for its members. These issues appeared only in the Uruguay Round, when concessions in terms of market access were negotiated, through tariffs reduction and/or the removal of non-tariff barriers (HOEKMAN; KOSTECKI, 1995).

The creation of the WTO, based on the commitments set out in the Uruguay Round, has made international trade more predictable. However, it caused the cost of national governments' freedom to fully define their own trade practices. These restrictions limit the scope of trade policies to WTO-defined laws by preventing actions to promote unfair competitiveness. On the 
other hand, these laws protect members' competitiveness against illegal actions promoted by WTO partners (HORN; MAVROIDIS; SAPIR, 2010).

In addition to the greater predictability of international trade and fairness in competition, WTO's rules are guided by two principles: non-discrimination and reciprocity. The first principle states that organization's members are bound to treat the products of other members in the same way as the products of any other country. Regarding the entry of a product into the national market, the imported product must be treated equally as the domestic similar product (WTO, 2018).

The second principle, reciprocity, establishes that there should be no favored nation. The negotiations are carried out through an exchange of concessions in access to markets, and each country must obtain counterparts for what it is willing to offer. It is the principle of reciprocity that makes it possible for liberalization to be broader, based on a multilateral code of conduct. In case of violation of the rules, countries can resolve disputes in the WTO's forums (WTO, 2018).

Trade protection mechanisms may be invoked whenever a nation believes that another WTO's member has acted to nullify or reduce the benefits of a previously agreed concession or in the event of a breach in an organizational rule. In such cases, the impaired country may conduct bilateral consultations and/or use the Dispute Settlement Body. These forums allow countries to reach a peaceful agreement, avoiding unilateral retaliatory measures (WTO, 2018).

In cases where bilateral agreements are unsuccessful, the member may bring the dispute for the Dispute Settlement Body's judgment. Thereafter, the country that violates the WTO's agreements will be subject to two types of penalties: either to offer compensation to the other party or to be subject to retaliation. The retaliatory power varies in function of the market importance of the sued country. Thus, large economies an advantage over small ones (HORN; MAVROIDIS; SAPIR, 2010).

\subsubsection{Forum shopping: Where to resolve trade disputes?}

In identifying a possible incompatibility with a trading partner, the country should determine whether and where to file its petition (ROSENDORFF; SMITH, 2018). After the creation of the regional blocs and of the WTO itself, the practice of the so-called forum shopping became more widespread. Forum shopping is the practice where "members select 
among overlapping institutions in deciding which (if any) to petition in trying to resolve their conflicts" (BUSCH, 2007, p. 736).

The regional blocs have their own resolution agreements and forums, which becomes one more option for member states. According to Fattore (2018), trade conflicts between Mexico and the United States, for example, are defined in both the regional forums (NAFTA) and in those of the WTO. Turning to non-regional bodies to solve any trade conflicts does not attempt to go against regional trade rules. In fact, a non-regional body such as the WTO can be used as a third party in a dispute with a regional partner (PAUWELYN; SALLES, 2009; DAVEY; SAPIR, 2009).

The influence of interest groups plays a decisive role in the forum selection process. Governments are responsive to interest groups because they are dependent on them in future elections (FATTORE, 2012). Thus, countries tend to enter disputes pleaded by these groups, but always considering options that both are more likely to yield a positive result and require less spending of resources (DAVIS, 2009).

In addition, Busch (2007) emphasizes that the choice of a forum will depend much on the conflict itself. Clearly, regional disputes tend to be discussed within each blocs' own forum. However, if the dispute has more global implications and several states are involved, WTO forums are usually preferable. This ensures the decision neutrality by preventing partners from exerting a hegemonic influence on the process.

Finally, another factor influencing the choice of the forum is the legal capacity of the country. The concept of legal capacity can be understood as the full ability to participate in commercial forums and to verify the commitment of partners to follow the rules of the agreements (BUSCH et al., 2009). For Davis (2009), developing countries tend to choose regional forums because of the high resources employed in the WTO. In addition, there is often a lag in the technical team, which prevents full follow-up of the proceedings in this forum. On the other hand, the EU and the US tend to prefer to pursue the WTO disputes because they already know the system and have enough resources for actions in Geneva.

Besides the legality of forum shopping, the effects of this system are questioned. The study of Salles (2014, p. 16) raises the concern that "forum shopping [...] raises questions of legitimacy, fairness, systemic integrity, and cost." Therefore, understanding how the process dynamics in the WTO dispute settlement works may highlight some aspects in this discussion. 


\section{METHODOLOGY}

\subsection{Social Network Analysis}

The purpose of social network analysis is to identify and measure a community composed of people, groups, companies, countries, among other so-called actors of the network (GRANOVETTER, 1973). The peculiarity of this type of study is the emphasis given to the ties that unite the different actors and not to the individual characteristics of each actor (LAZZARINI, 2008). The network therefore is composed of nodes that represent the actors and of ties representing their relationships with that network. Thus, the social network analysis provides important indicators for the evaluation of collectivities.

The multidisciplinary character of the social network analysis makes it possible to observe a series of relationships, arousing the interest of researchers of the most varied fields of knowledge. Among these relations, the main indicators are: size, density, centrality, and network cohesion (SILVA, 2003). In this research, we used two indicators of centrality (see section 3.3), that is, of how many other network members a particular actor is connected to.

This analysis is performed by measuring two numbers: (i) that of connections that an actor has inside the network and (ii) that of paths that pass through it for the integration with two other disconnected actors. Greater centrality indicates an actor's greater ability to directly or indirectly access other actors in the network. Therefore, the degree of centrality means the possibility of "control" of the network, a greater capacity to influence and intermediate the various relationships between members (ALEJANDRO; NORMAN, 2005).

\subsection{Data information}

The purpose of this study was to analyze the configuration of trade disputes in WTO's Dispute Settlement Body. The network structure was based on the reports available on the organization's website. In 2014, this organization had 164 members and an additional 25 countries in the acceptance process (WTO, 2018). The countries on which this research concentrates are those listed in at least one of the proceedings of the Dispute Settlement Body, either in the complaint proceeding or in that of the accused country, totaling 65 actors. The other WTO members that do not appear in any proceeding in that particular year are outside this network. 
For each case the Dispute Settlement Body has in place, the WTO provides a report with all the background information, such as what country has been sued, what was charged, what rule was allegedly broken, and the final outcome of the proceeding. This research analyzed only the information concerning the countries involved, not the reasons or the process results.

\subsection{Analysis method}

The analyses made in this study were descriptive. We sought to bring centrality indicators based on traditional methods of network analysis. These indicators were considered fundamental to the research aim insofar as they allowed analyzing the developed and emerging countries according to the disputes in the WTO's forum.

To define the centrality in the network, two measures were used. The first one was the $\mathrm{k}$-core indicator to create subgroups in the network. A subgroup is formed by actors that have links among each other, which may suggest common characteristics that differentiate them from other members of the network. In the context of WTO's disputes, a group of countries may present common characteristics, for example, being present in a few processes and with few countries (RUIZ-SANTACRUZ; GORDO, 2018).

The second measure of centrality is the centrality index itself, which indicates the number of connections that an actor has in the network, whether directly or indirectly. This indicator is important when analyzing a member influencing power over other actors in the network. In general, more central actors have greater power of influence (RUIZ-SANTACRUZ; GORDO, 2018). The difference between the two indexes used is that, while the k-core index creates a group of countries with similar characteristics of centrality, the index of centrality analyzes each actor individually. We used the software UCINET, version 6.186, for data processing and network composition. In addition, the software served to support the development of graphical representations.

\section{ANALYSIS AND DISCUSSION OF RESULTS}

The analysis was conducted with countries involved in proceedings in the World Trade Organization's Dispute Settlement Body in 2014. Sixty-five out of (more than) 164 members were involved in at least one proceeding in that year, as a defendant or an applicant (see Figure 1). Therefore, there were 99 members that did not participate in any dispute in this forum in 
2014, pointing to the high presence of fragmentation within the network (SILVA, 2003; RUIZSANTACRUZ; GORDO, 2018).

The first analysis was performed by using the k-core index, which analyzes the subgroups of each actor through its centrality in the network (see Table 1). The value of the index varies between 1 and 6 , the value 1 being the least integrated subgroup and the value 6 being the most integrated into the network (RUIZ-SANTACRUZ; GORDO, 2018). Thus, we can identify that the most integrated group in the network was formed by eleven actors: Argentina, Australia, Brazil, Canada, United States, European Union, India, Indonesia, Japan, South Korea, and New Zealand.

Figure 1 - Network of countries involved in processes arbitrated by the WTO in 2014

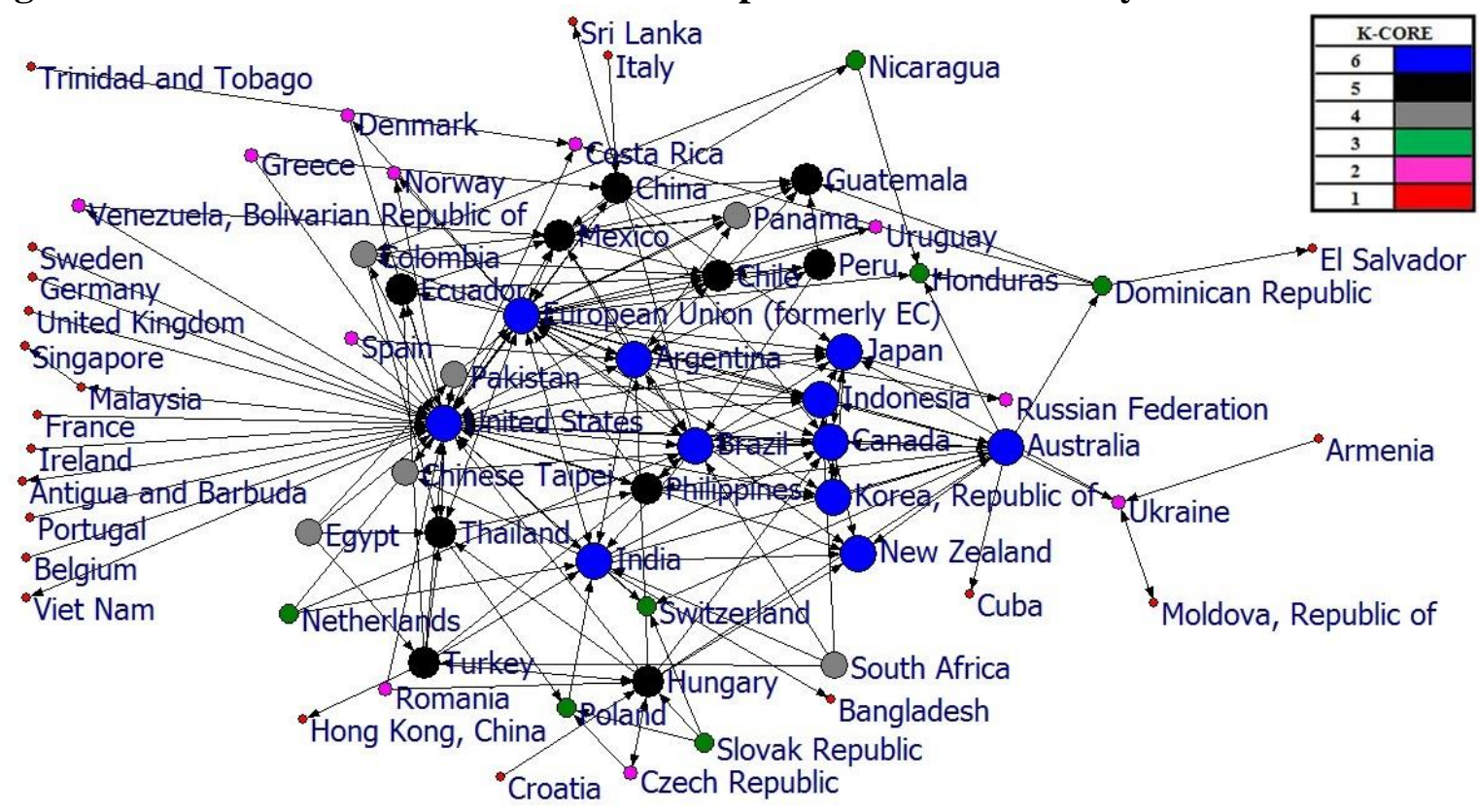

Source: developed by the authors.

In regard to this subgroup, we can identify that only New Zealand does not participate as a member of the Group of Twenty (G20). The purpose of this group is to promote international negotiations in economic and trade discussions. Considered an extension of the Group of Seven (G7), the member states represent approximately $90 \%$ of global production, concentrate more than $80 \%$ of international trade, and make up two-thirds of the world's population. Unlike the $\mathrm{G} 7$, this group has increased their representation by including developed and emerging member states (OECD, 2007). The presence of emerging countries in this identified group of disputes in the WTO makes sense according to Aggarwal and Evenett (2013, p. 6), who state that emerging countries have gained power in WTO, and "cannot so easily be pressured, marginalized or ignored by richer members." 
This result corroborates the one proposed by Davis (2009), who argues that countries with a high volume of trade tend to seek non-regional forums, such as the WTO. This happens because they tend to use more resources in trade disputes and to develop a more qualified team to conduct their processes (BUSCH et al., 2009; FATTORE, 2018).

On the contrary, the group that is less integrated into the network is formed by smaller economies that usually have constraints of resources for participation in multilateral forums (ROSENDORFF; SMITH, 2018) or by European Union member states, which work together in the WTO's forum and have a forum of their own (FATTORE, 2018). The use of WTO's forum by these countries only happens when regional discussions do not advance (PAUWELYN; SALLES, 2009; DAVEY; SAPIR, 2009).

Table 1 - K-core indices of the network actors

\begin{tabular}{c|l}
\hline K-Core index & Network actors \\
\hline 6 & $\begin{array}{l}\text { Argentina, Australia, Brazil, Canada, U.S, European Union, India, Indonesia, Japan, South } \\
\text { Korea, New Zealand. }\end{array}$ \\
\hline 5 & Chile, China, Ecuador, Guatemala, Hungary, Mexico, Peru, Philippines, Thailand, Turkey. \\
\hline 4 & South Africa, Colombia, Egypt, Pakistan, Panama, Taiwan. \\
\hline 3 & Slovakia, Netherlands, Honduras, Nicaragua, Poland, Dominican Republic, Switzerland. \\
\hline 2 & $\begin{array}{l}\text { Costa Rica, Denmark, Spain, Greece, Norway, Czech Republic, Romania, Russia, } \\
\text { Ukraine, Uruguay, Venezuela. }\end{array}$ \\
\hline 1 & $\begin{array}{l}\text { Germany, Antigua and Barbuda, Armenia, Bangladesh, Belgium, Croatia, Cuba, El } \\
\text { Salvador, France, Hong Kong, China, Ireland, Italy, Malaysia, Moldova, Portugal, United } \\
\text { Kingdom, Singapore, Sri Lanka, Sweden, Trinidad and Tobago, Vietnam. }\end{array}$ \\
\hline
\end{tabular}
Source: developed by the authors.

The second step of analysis was to verify the centrality index and relate its results to the those of the k-core index (see Table 3, Appendix). The main actors in this network are therefore the United States and the European Union, with rates of 0.60 and 0.53, respectively. The first actor is the largest economy in the world, having a representative weight in international trade. The second most central actor is an economic bloc that brings together most of the European countries and, as a whole, is the second largest economic force in the world (OECD, 2007).

The bond between these two actors was the strongest in the network in that year (Figure 2), with 19 cases initiated by the United States (against the European Union) and 32 cases opened by the European Union (against the United States). This confirms the perspective of Davis (2009), for whom the United States and the European Union prefer to conduct the disputes in the global forums, as these members have resources and a more prepared team to conduct the proceedings.

Despite this, Fattore (2018) argues that the other countries prefer to confront these actors, especially the United States, in global forums to mitigate the risk of hegemonic influence 
in the regional forums. This argument is corroborated by the presence of Canada, the third most central, and Mexico, the tenth most central, in the WTO dispute network. Since these countries are together in NAFTA, there is evidence in the results that suggest that the member states of this bloc use the WTO to arbitrate some disputes, and others are addressed in NAFTA, these choices being made through the forum shopping process.

Figure 2 - Network without the main actors: United States and European Union

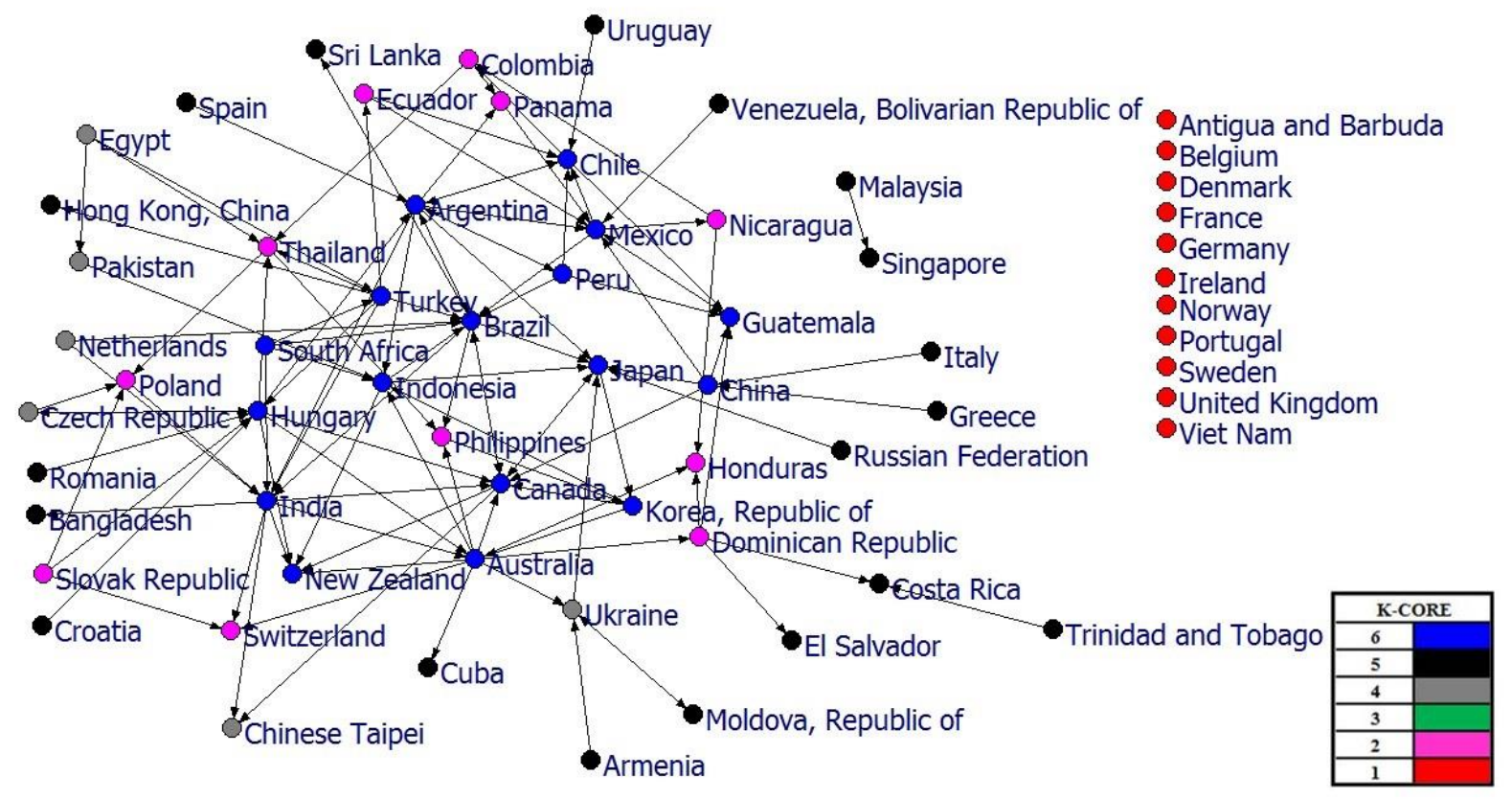

Source: developed by the authors.

Another piece of evidence that supports Fattore's argument (2018) is that when we excluded European Union and the United States from the analysis, 11 countries were isolated in the network: Antigua and Barbuda, Belgium, Denmark, France, Germany, Ireland, Norway, Portugal, United Kingdom, Sweden, and Vietnam. This means that these 11 countries are not part of any other WTO process with other actors in 2014, preferring to address the European Union and the United States in the WTO's forum, because there was no regional forum available (non-European countries) or because they preferred to restrict the hegemonic power of these partners (SATTLER; BERNAUER, 2011; TROMMER, 2017).

Table 2 - Centrality indices per network member

\begin{tabular}{r|l|r}
\hline Position & \multicolumn{1}{|c|}{ WTO members } & Centrality index \\
\hline 1 & United States & 0.603 \\
\hline 2 & European Union & 0.533 \\
\hline 3 & Canada & 0.273 \\
\hline 4 & China & 0.246 \\
\hline 5 & Brazil & 0.196 \\
\hline 6 & India & 0.186 \\
\hline 7 & Japan & 0.167 \\
\hline
\end{tabular}

(TO BE CONTINUED) 
FORUM SHOPPING EVIDENCE IN THE WORLD TRADE ORGANIZATION: A SOCIAL NETWORK ANALYSIS OF DISPUTES BETWEEN MEMBER STATES

\begin{tabular}{c|l|r}
\multicolumn{2}{l}{} \\
\hline CONTINUATION) & 0.156 \\
\hline 8 & South Korea & 0.148 \\
\hline 9 & Argentina & 0.145 \\
\hline 10 & Mexico & \\
\hline
\end{tabular}

Source: developed by the authors.

Another interesting finding of the research was the low participation of certain regions around the globe. When we analyzed the WTO's member states by continent of origin, we identified that North American, South American and Asian countries were positioned at the center of the network, while the members from Europe, Central America, and Africa are in a peripheral position (Figure 3). With regard to African countries, only the largest economies are part of the network (South Africa and Egypt). The other countries within that continent were not part of the WTO proceedings in the year analyzed.

Figure 3 - Network explaining the origin of the actors by the continent of origin

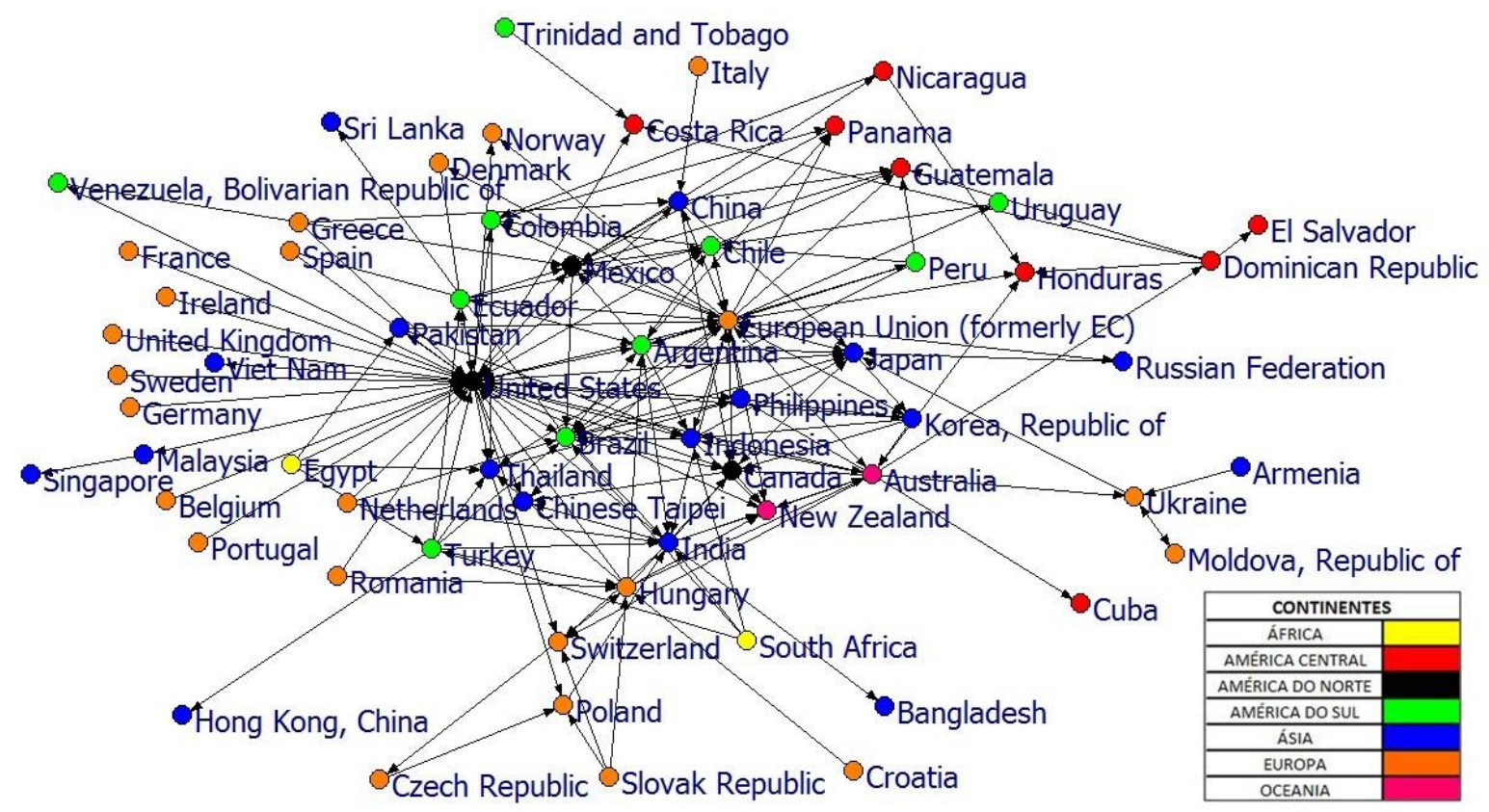

Notes: Africa in yellow; Asia in blue; Central America in red; Europe in orange; North America in black; Oceania in pink; and South America in green.

Source: developed by the authors.

As Davis (2009) suggests, opening up proceedings in a multinational forum such as the WTO requires high financial resources from the countries involved. Small governments are, in general, struggled by these financial costs (FINNEMORE; GOLDSTEIN, 2013). In addition, countries need to develop their legal capacity to deal with more resourceful members. That leads countries to decide either not to participate in these disputes or only to support countries with similar demands (BUSCH et al., 2009). Despite there being concerns about the fairness of regional trade agreement forums (SALLES, 2014), the WTO forum ends up becoming an arena with few opportunities for participation from smaller economies. 
The WTO Secretariat has identified 635 preferential trade agreements, which causes a fragmentation of world trade governance (TROMMER, 2017; WTO, 2018). For Aggarwal and Evenett (2013), this is the result of two simultaneous forces that are changing international trade, the first being the increased power of the major emerging economies in the WTO, which makes this forum less vulnerable to the influence of core countries. The second force, resulting from the first, is the European Union's and the United States' preference for operating in the rules of preferential trade agreements to ensure their commercial interests (FATTORE, 2018). However, Trommer (2017) argues that there are limitations in the rule-based nature of global trade governance.

These agreements undermine efforts for a transparent global trade, whose rules are simple and where cooperation prevails (TROMMER, 2017). In what the author calls "Preferential Trade Agreements Era," free trade institutions are more fragile and more conducive to the tricks of more resourceful partners. For this author, the forum shopping prejudices the global trade by reducing WTO's centralized governance. That means greater difficulty in solving multinational concerns such as global warming (SILVA; MARTINS, 2018).

\section{CONCLUSIONS}

International trade has become larger and more elaborate, embracing almost every country, permitting the increase of their participation. However, increased trade flows result in more hostility between countries, who in turn seek international bodies to arbitrate their conflicts. The main body is led by the World Trade Organization, which proposes rules and monitors compliance by its members.

In this research, we investigated how the relations between the WTO's members were configured, identifying the dichotomy between central and emerging countries from the concept of forum shopping through social network analysis. The main finding was the clear disparity in the use of the Dispute Settlement Body among central and emerging WTO members. These results show that the so-called forum shopping is present in the decisions of smaller countries seeking regional forums to mediate their trade disputes, a fact that also occurs between commercial partners of the same bloc. The regional forums rules are easier to be reshaped by bigger economies. 
Although previous studies have shown the existence of forum shopping (DAVIS, 2009; BUSCH et al., 2009), this study evidences this phenomenon through the method of analysis of social networks. This implies that the WTO forum is seen as a court that does not provide opportunities for members without financial or legal resources. In addition, it creates an advantageous position for countries with more resources.

As a limitation of this paper, the analysis does not allow for speculation on the importance of the product type in the forum shopping decision. Another limitation is that no indepth analysis was carried out on cases between member states within the same bloc, in particular, members of the European Union. These non-answered gaps could be subjects to be explored in future related research.

\section{REFERENCES}

AGGARWAL, V.; EVENETT, S. A Fragmenting Global Economy: A Weakened WTO, Mega FTA s, and Murky Protectionism. Swiss Political Science Review, v. 19, n. 4, p. 550-557, 2013.

ALEJANDRO, V.; NORMAN, A. Manual introdutório à análise de redes sociais. UAEMUniversidad Autonoma Del Estado de Mexico, 2005.

BALDONE, S.; SDOGATI, F.; TAJOLI, L. On some effects of international fragmentation of production on comparative advantages, trade flows and the income of countries. The World Economy, v. 30, n. 11, p. 1726-1769, 2007.

BALDWIN, R. E. Global supply chains: why they emerged, why they matter, and where they are going, 2012.

BANACLOCHE, S. P. Intra-regional trade in services in South America: An input-output approach. RAM. Revista de Administração Mackenzie, v. 18, n. 6, p. 47-70, 2017.

BONAGLIA, F.; GOLDSTEIN, A.; MATHEWS, J. Accelerated internationalization by emerging markets' multinationals: The case of the white goods sector. Journal of World Business, v. 42, n. 4, p. 369-383, 2007.

BUSCH, M. Overlapping institutions, forum shopping, and dispute settlement in international trade. International Organization, v. 61, n. 4, p. 735-761, 2007. 
BUSCH, M.; REINHARDT, E.; SHAFFER, G. Does legal capacity matter? A survey of WTO Members. World Trade Review, v. 8, n. 4, p. 559-577, 2009.

CLING, J. The future of global trade and the WTO. Foresight, v. 16, n. 2, p. 109-125, 2014.

DAVEY, W.; SAPIR, A. The soft drinks case: the WTO and regional agreements. World Trade Review, v. 8, n. 1, p. 5-23, 2009.

DAVIS, C. L. Overlapping institutions in trade policy. Perspectives on politics, v. 7, n. 1, p. 25-31, 2009.

ELMS, D.; LOW, P. Global Value Chains in a Changing World, Geneva: World Trade Organization, 2013.

ESTRIN, S.; MEYER, K.; PELLETIER, A. Emerging Economy MNEs: How does home country munificence matter? Journal of World Business, v. 53, n. 4, p. 514-528, 2018.

FATTORE, C. Forum Shopping and Fairness in Mexico-United States Trade Disputes. Latin American Policy, v. 9, n. 1, p. 77-93, 2018.

Interest Group Influence on WTO Dispute Behaviour: A Test of State Commitment. Journal of World Trade, v. 46, n. 6, p. 1261-1280, 2012.

FINNEMORE, M.; GOLDSTEIN, J. (Ed.). Back to basics: State power in a contemporary world. Oxford University Press, 2013.

GIBBON, P.; PONTE, S. Trading down: Africa, value chains, and the global economy. Temple University Press, 2005.

GRANOVETTER, M. S. The Strength of Weak Ties. American Journal of Sociology. 78: 1360-1380, 1973.

HOEKMAN, B.; KOSTECKI, M. The political economy of the world trading system: from Gatt to WTO. Oxford: Oxford University Press, 1995.

HOPEWELL, K. The BRICS - merely a fable? Emerging power alliances in global trade governance. International Affairs, v. 93, n. 6, p. 1377-1396, 2017. 
HORN, H.; MAVROIDIS, P.; SAPIR, A. Beyond the WTO? An anatomy of EU and US preferential trade agreements. The World Economy, v. 33, n. 11, p. 1565-1588, 2010.

JACKSON, J. Sovereignty, the WTO, and Changing Fundamentals of international law. Cambridge: CUP, p. 145, 2006.

JOHANSON, J.; VAHLNE, J. The internationalization process of the firm-a model of knowledge development and increasing foreign market commitments. Journal of international business studies, p. 23-32, 1977.

; VAHLNE, J. The Uppsala internationalization process model revisited: From liability of foreignness to liability of outsidership. Journal of international business studies, v. 40, n. 9, p. 1411-1431, 2009.

KAPLINSKY, R.; READMAN, J. Globalization and upgrading: what can (and cannot) be learnt from international trade statistics in the wood furniture sector? Industrial and Corporate Change, v. 14, n. 4, p. 679-703, 2005.

LAZZARINI, S. G. Empresas em rede. São Paulo: Cengage Learning, 2008.

ORGANIZATION FOR ECONOMIC COOPERATION AND DEVELOPMENT - OECD, Staying competitive in the global economy: moving up the global value chain. 2007. Available in:

<http://www.oecd.org/industry/ind/stayingcompetitiveintheglobaleconomymovingupthevalue chainsynthesisreport.htm> Access: Sept. 20, 2018.

PAUWELYN, J.; SALLES, L. Forum shopping before international tribunals: (real) concerns, (im) possible solutions. Cornell Int'l LJ, v. 42, p. 77, 2009.

ROSENDORFF, B. P.; SMITH, A. Domestic political determinants of the onset of WTO disputes. The Review of International Organizations, v. 13, n. 2, p. 243-272, 2018.

RUIZ-SANTACRUZ, J.; GORDO, J. Descripción de campos migratorios internos colombianos usando análisis de redes sociales. Redes. Revista hispana para el análisis de redes sociales, v. 29, n. 1, p. 65-75, 2018.

SALLES, L. Forum shopping in international adjudication: the role of preliminary objections. Cambridge University Press, 2014. 
SASSEN, S. Globalization and its discontents: Essays on the new mobility of people and money. 1999.

SATTLER, T.; BERNAUER, T. Gravitation or discrimination? Determinants of litigation in the World Trade Organisation. European journal of political research, v. 50, n. 2, p. 143167, 2011.

SILVA, M. Redes sociais intraorganizacionais informais e gestão: um estudo nas áreas de manutenção e operação da planta HYCO-8, Camaçari, BA. 2003.223 f. Dissertação (Mestrado em Administração) - Curso de Mestrado em Administração, Núcleo de Pós-Graduação da Escola de Administração, Universidade Federal da Bahia, Salvador, 2003.

SILVA, A.; MARTINS, N. Potências Climáticas e o Órgão de Solução de Controvérsias da OMC: O Caso dos Biocombustíveis. Revista Eletrônica de Direito do Centro Universitário Newton Paiva, Belo Horizonte, n. 34, p. 45-58, jan./abr. 2018.

TROMMER, S. The WTO in an era of preferential trade agreements: Thick and thin institutions in global trade governance. World Trade Review, v. 16, n. 3, p. 501-526, 2017.

WORLD TRADE ORGANIZATION - WTO. Available at: <https://www.wto.org/>. Access: Sept. 15, 2018.

ZINN, W. Globalização e complexidade em supply chains. Revista Tecnologística, São Paulo, janeiro e fevereiro, 2012. 


\section{APPENDIX}

Table 3 - Centrality indices per member of the network

\begin{tabular}{|c|c|c|c|c|c|}
\hline$\#$ & WTO members & Centrality index & \# & WTO members & Centrality index \\
\hline 1 & Antigua and Barbuda & 0.0100 & 35 & South Korea & 0.1560 \\
\hline 2 & Argentina & 0.1480 & 36 & Malaysia & 0.0100 \\
\hline 4 & Australia & 0.0740 & 37 & Mexico & 0.1450 \\
\hline 5 & Bangladesh & 0.0030 & 38 & Netherland & 0.0170 \\
\hline 6 & Belgium & 0.0310 & 39 & New Zealandia & 0.0410 \\
\hline 7 & Brazil & 0.1960 & 40 & Nicaragua & 0.0030 \\
\hline 8 & Canada & 0.2730 & 41 & Norway & 0.0370 \\
\hline 9 & Chile & 0.0680 & 42 & Pakistan & 0.0310 \\
\hline 10 & China & 0.2460 & 43 & Panama & 0.0330 \\
\hline 11 & Taiwan, China & 0.0270 & 44 & Peru & 0.0270 \\
\hline 12 & Colombia & 0.0250 & 45 & Filipinas & 0.0600 \\
\hline 13 & Costa Rica & 0.0100 & 46 & Polonia & 0.0050 \\
\hline 15 & Cuba & 0.0010 & 47 & Portugal & 0.0100 \\
\hline 17 & Denmark & 0.0190 & 48 & Romania & 0.0110 \\
\hline 18 & Dominican Republic & 0.0040 & 49 & Russia & 0.0300 \\
\hline 19 & Equator & 0.0260 & 51 & Slovakia & 0.0010 \\
\hline 20 & Egypt & 0.0130 & 52 & South Africa & 0.0080 \\
\hline 22 & European Union & 0.5330 & 53 & Spain & 0.0230 \\
\hline 23 & France & 0.0410 & 54 & Sri Lanka & 0.0030 \\
\hline 24 & Germany & 0.0200 & 55 & Sweden & 0.0100 \\
\hline 25 & Greece & 0.0250 & 56 & Switzerland & 0.0150 \\
\hline 26 & Guatemala & 0.0380 & 57 & Thailand & 0.0900 \\
\hline 27 & Honduras & 0.0280 & 59 & Turkey & 0.0330 \\
\hline 28 & Hong Kong, China & 0.0010 & 60 & Ukraine & 0.0040 \\
\hline 29 & Hungary & 0.0210 & 61 & United Kingdom & 0.0310 \\
\hline 30 & India & 0.1860 & 62 & United States & 0.6030 \\
\hline 31 & Indonesia & 0.0760 & 63 & Uruguay & 0.0100 \\
\hline 32 & Ireland & 0.0310 & 64 & Venezuela & 0.0130 \\
\hline 33 & Italia & 0.0040 & 65 & Vietnam & 0.0200 \\
\hline 34 & Japan & 0.1670 & & & \\
\hline
\end{tabular}

Source: developed by the authors. 